\title{
EFEK PEMBERIAN BUAH PEPINO (Solanum maricatum) TERHADAP PERUBAHAN KADAR KOLESTEROL TOTAL PADA TIKUS HIPERKOLESTEROLEMIA
}

Oleh:

\author{
PUGUH ARIF PRIAMBUDI,*) RINDIANI, dan DAHLIA INDAH AMARETA**)
}

\begin{abstract}
ABSTRAK
Latar belakang Hiperkolesterolemia merupakan faktor risiko penyakit kardiovaskuler yang menjadi penyebab kematian utama di dunia. Salah satu alternatif yang dapat menurunkan kadar kolesterol dalam darah adalah makanan yang memiliki serat tinggi. Serat dapat menurunkan kolesterol dalam darah salah satunya dengan meningkatkan ekskresi empedu dan fermentasi dari serat akan menghasilkan asam lemak rantai pendek. Buah pepino adalah buah yang memiliki serat tinggi sebesar 5 gr per 100 gr.

Tujuan Mengetahui pengaruh pemberian buah pepino terhadap kadar kolesterol total tikus hiperkolesterolemia. .

Metode Penelitian ini merupakan penelitian eksperimental (True Experimental). Desain penelitian yang digunakan adalah rancangan Pretest-Posttest dengan kelompok kontrol (Pretest-Posttest with Control Group). Sampel adalah tikus wistar jantan berusia 2 bulan dan diinduksi diet tinggi lemak dan diberi buah pepino.

Hasil sampel diinduksi diet tinggi lemak dan diberi buah pepino dengan dosis 9 gr, 10 gr, dan 11 gr/200 gr BB selama 14 hari. Kadar kolesterol total diperiksa dan dilakukan pengolahan data dengan uji tberpasangan dan Annova, dilanjutkan uji LSD. Dari hasil pengolahan tersebut terdapat perbedaan kadar kolesterol total sebelum dan sesudah diberi perlakuan pada masing-masing kelompok.

Kesimpulan pemberian buah pepino dengan dosis 9 gr/200 gr BB tikus/hari mampu menurunkan 6,5\% kadar kolesterol total, dosis $10 \mathrm{gr} / 200 \mathrm{gr} \mathrm{BB}$ tikus/hari mampu menurunkan 8,5\% kadar kolesterol total dan dosis $11 \mathrm{gr} / 200 \mathrm{gr}$ BB tikus/hari mampu menurunkan 12,4\% kadar kolesterol total.
\end{abstract}

Kata kunci: Buah Pepino (Solanum Maricatum), Kadar Kolesterol Total, Hiperkolesterolemia

\section{PENDAHULUAN}

Hiperkolesterol merupakan suatu keadaan yang ditandai dengan adanya kenaikan kolesterol LDL, kenaikan kadar kolesterol total dan trigliserida serum (Nainggolan dan Cornelis, 2005). Tingginya kadar kolesterol total dengan peningkatan kadar LDL dan rendahnya kadar kolesterol HDL dapat meningkatkan risiko aterosklerosis dan penyakit kardiovaskuler. Salah satu alternatif yang dapat menurunkan kadar kolesterol dalam darah adalah makanan yang memiliki serat tinggi. Serat memiliki fungsi dalam menurunkan kolesterol dalam darah. Mekanisme serat dapat menurunkan kolesterol yaitu dengan meningkatkan ekskresi empedu, menghambat absorpsi kolesterol, mencegah sintesis kolesterol karena fermentasi serat menghasilkan Asam Lemak Rantai Pendek (SCFA), serta dapat menurunkan jumlah energi makanan sehingga mengurangi sintesis kolesterol (Lupton, 2000).

Buah Pepino adalah buah yang memiliki serat tinggi. Penelitian sebelumnya serat dalam buah pepino sebesar 5 gr per 100 gr. Buah ini merupakan alternatif yang sangat efisien menurunkan kadar kolesterol dalam darah setelah jambu biji yang juga mengandung serat 5 gr per 100 gr. Selain seratnya yang tinggi buah pepino juga mengandung zat aktif lain seperti alkaloid, steroid dan antosianin. Selain itu setiap $100 \mathrm{gr}$ pepino juga mengandung vitamin $\mathrm{C} 25.1 \mathrm{mg}$, protein $0.6 \mathrm{gr}$, betakaroten $26.6 \mathrm{mg}$ dan asam sitrat (Husnah, 2009 dan IPGRI 2004).

Masyarakat beranggapan bahwa penyakit tinggi kolesterol hanya bisa disembuhkan dengan obat saja. Namun pengobatan alternatif cenderung menggunakan obat dari alam, sehingga dapat memanfaatkan buah pepino yang memiliki serat tinggi dan mudah didapat. Karenanya perlu adanya suatu penelitian mengenai kegunaan serat dari sayuran dan buah-buahan yang efektif dimanfaatkan untuk menurunkan kadar kolesterol dalam darah secara non-farmakologis, yaitu buah pepino.

Tujuan dari penelitian ini adalah Mengetahui efek pemberian buah pepino terhadap 
Puguh,Rindiani, dan Dahlia Indah A, Efek Pemberian Buah Pepino (Solanum maricatum) Terhadap Perubahan Kadar Kolesterol Total Pada Tikus Hiperkolesterolemia

perubahan kadar kolesterol total pada tikus hiperkolesterolemia.

\section{METODE}

Penelitian ini merupakan penelitian eksperimental (True Experimental). Desain penelitian yang digunakan adalah rancangan Pretest-Posttest dengan kelompok kontrol (Pretest-Posttest with Control Group) (Notoadmodjo, 2010).

Sampel yaitu tikus ( $R$. Norvegicus) yang dikondisikan hiperkolesterolemia, dilakukan randomisasi menjadi 5 kelompok yaitu kelompok kontrol positif (X0) yang setelah kondisi hiperkolesterolemia diberikan diet standar yaitu pakan pellet Turbo dan air minum.

Kelompok II (X1), adalah kelompok tikus hiperkolesterolemia yang diberi perlakuan diet standar dengan pemberian buah pepino dosis dosis I (9 gr/BB tikus)

Kelompok III (X2), adalah kelompok tikus hiperkolesterolemia yang diberi perlakuan diet standar dengan pemberian buah pepino dosis II (10 gr/BB tikus)

Kelompok IV (X3), adalah kelompok tikus hiperkolesterolemia yang diberi perlakuan diet standar dengan pemberian buah pepino dosis III (11 gr/BB tikus)

Kelompok V (X4), adalah kelompok tikus hiperkolesterolemia yang diberi diet standar dengan perlakuan pemberian obat simvastatin

\section{Prosedur Kerja}

1. Persiapan pakan buah pepino dan obat simvastatin

Pakan standar yang digunakan adalah pellet Turbo sebanyak \pm 50 gram/kelompok perlakuan/hari dan air minum aquades \pm 100 $\mathrm{ml} /$ hari. Produk perlakuan yang diberikan yaitu obat simvastatin dengan dosis 0,18 $\mathrm{mg} / \mathrm{kg}$ BB tikus dan buah pepino pada dosis I, II, dan III.

2. Pemilihan dan Pemeliharaan Tikus Percobaan Pemilihan 25 ekor tikus jantan Sprague Dawley, dengan berat $200-300$ gr, berumur 2-3 bulan. Pemilihan tikus secara randominasi menjadi lima kelompok yang sesuai dengan kriteria inklusi. Pengadaptasian tikus selama 7 hari, menggunakan pakan standar dan air minum. Tikus tersebut dikandangkan dengan kondisi cahaya dan ventilasi yang cukup dan pada suhu ruang yang sesuai, siklus gelap terang 12 jam (sekitar 25 - 290C) (Rochmawati, 2008).

Tikus percobaan ditempatkan pada tepat yang terpisah, setiap satu kandang digunakan untuk satu perlakuan atau kelompok.
Pemeliharaan tikus harus dengan menggunakan kotak tikus yang telah disiapkan, untuk memantau kesehatan tikus dengan cara mengamati keaktifan perilaku tikus setiap hari, pemeriksaan pakan, dan air minum. Sebelum pemberian pakan, kandang dan tempat kotoran dicuci terlebih dahulu, kandang tikus harus selalu diperhatikan kebersihannya, terutama pergantian serbuk gergaji yang dilakukan minimal sekali dalam seminggu, dan kotak tikus juga harus selalu dibersihkan. Apabila tikus mengalami sakit, maka akan segera melakukan pemisahan dan pengobatan (Khayrani, 2008).

3. Pemberian diet hiperkolesterolemia

Setelah tikus diadaptasikan selama 7 hari, 25 tikus diberikan diet hiperkolesterolemia dengan menggunakan otak sapi. Pemberian otak sapi sebanyak $2 \mathrm{ml} /$ tikus/hari melalui sonde lambung selama 28 hari. Otak sapi yang diberikan merupakan otak sapi yang telah dikukus dan diblender dengan perbandingan penambahan air 1:1.

Otak sapi diberikan pada tikus melalui oral dengan sonde lambung. Sebelum memasukkan sonde, posisi kepala dan keadaan mulut tikus harus diperhatikan. Ketika tikus dipegang dengan posisi terbalik pastikan posisi kepala menengadah atau posisi dagu sejajar dengan tubuh dan mulut sedikit terbuka. Pada saat perlakuan, tikus tetap diberi pakan standar (pelet turbo) dan air minum.

4. Pemeriksaan kadar kolesterol total (pre test) Sebelum melakukan pemeriksaan kadar kolesterol total tikus tahap awal (pre test), tikus harus dipuasakan selama 12 jam. Selama dipuasakan tikus tetap diberikan minum. Selanjutnya dilakukan pengambilan darah pada arteri ventral ekor kemudian dilakukan pemeriksaan kadar kolesterol total darah tikus di Laboratorium Klinik Prosenda Jember dengan metode GOD-POD dan menggunakan alat flositometri.

5. Perlakuan pemberian obat dan buah pepino Perlakuan pada tikus dilakukan selama 14 hari dengan pemberian buah pepino dengan dosis bertingkat yaitu dosis $\mathrm{I}=9 \mathrm{gr} / \mathrm{BB}$ tikus, dosis $\mathrm{II}=10 \mathrm{gr} / \mathrm{BB}$ tikus, dosis $\mathrm{III}=11$ $\mathrm{gr} / \mathrm{BB}$ tikus dan pemberian obat simvastatin $0,18 \mathrm{mg} / \mathrm{kgBB}$ tikus. Selama masa perlakuan tikus tetap diberikan pakan standar (pellet turbo) dan air minum aquadest ad Libitum. Pemberian buah pepino dilakukan dengan potongan buah diberikan $2-3 \mathrm{kali} / \mathrm{hari}$ dan pemberian obat dilakukan dengan sonde lambung diberikan 2 - 3 kali/hari.

6. Pemeriksaan kadar kolesterol total (post test) 
Melakukan pemeriksaan kadar kolesterol total tikus tahap akhir (post test) melalui ekor tikus dengan prosedur yang sama dengan pemeriksaan kadar kolesterol total (pre test).

7. Pemusnahan tikus

Setelah pemeriksaan kadar kolesterol total tikus tahap akhir selesai, dilakukan pemusnahan tikus dengan cara semua tikus ditempatkan dalam ruang tertutup kemudian diinhalasi dengan kloroform. Setelah tikus dipastikan mati, kemudian dibungkus rapat dengan plastik dan dikubur di tempat yang telah disediakan.

8. Melakukan uji statistik data

\section{HASIL DAN PEMBAHASAN}

Rata - rata kadar kolesterol total sebelum dan sesudah perlakuan masing-masing kelompok perlakuan disajikan dalam Gambar 1.

Gambar 1, menunjukkan rata-rata kadar kolesterol total pre test pada kelompok perlakuan dengan nilai tertinggi $70,4 \mathrm{mg} / \mathrm{dl}$ dan terendah 67 $\mathrm{mg} / \mathrm{dl}$. Post test nilai tertinggi $67,4 \mathrm{mg} / \mathrm{dl}$ dan terendah $60,6 \mathrm{mg} / \mathrm{dl}$. Peningkatan kadar kolesterol total dalam darah adalah akibat induksi makanan diet tinggi lemak dengan pemberian diet otak sapi.

Makanan berperan penting dalam mempengaruhi kadar kolesterol dalam darah. Kolesterol meningkat karena asupan yang berasal dari lemak hewani seperti otak sapi (Guyton, 2006). Senyawa kolesterol ini disintesis di banyak

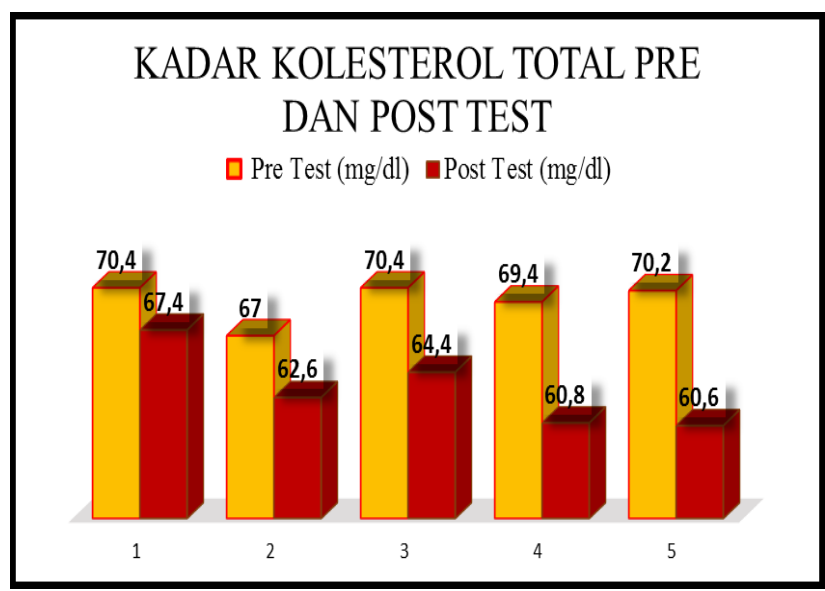

Gambar 1. Grafik perbedaan kadar kolesterol total sebelum dan sesudah perlakuan

Tabel 1 Kadar Kolesterol Total (mg/dl) Menurut Kelompok Perlakuan (Pre Test dan Post Test)

\begin{tabular}{cccc}
\hline \multirow{2}{*}{ Kelompok } & \multicolumn{2}{c}{ Rerata Kolesterol Total (mg/dl) } & \multirow{2}{*}{$p$} \\
\cline { 2 - 3 } & Pre Test & Post Test & \\
\hline Kontrol Positif (T1) & $70,4 \pm 2,7$ & $67,4 \pm 1,7$ & $0,005^{\mathrm{b}}$ \\
Perlakuan 1 (T2) & $67,0 \pm 3,0$ & $62,6 \pm 2,4$ & $0,000^{\mathrm{b}}$ \\
Perlakuan 2 (T3) & $70,4 \pm 1,1$ & $64,4 \pm 2,1$ & $0,002^{\mathrm{b}}$ \\
Perlakuan 3 (T4) & $69,4 \pm 1,1$ & $60,8 \pm 0,8$ & $0,000^{\mathrm{b}}$ \\
Perlakuan 4 (T5) & $70,2 \pm 2,3$ & $60,6 \pm 0,9$ & $0,000^{\mathrm{b}}$ \\
& $0,104^{\mathrm{a}}$ & $0,000^{\mathrm{a}}$ & \\
\hline
\end{tabular}

Keterangan :

a = Uji One Way Annova

$\mathrm{b}=\mathrm{Uji}$ Paired T-test 
Puguh,Rindiani, dan Dahlia Indah A, Efek Pemberian Buah Pepino (Solanum maricatum) Terhadap

Perubahan Kadar Kolesterol Total Pada Tikus Hiperkolesterolemia

Tabel 2 Prosentase Perubahan Kadar Kolesterol Total Pretest dan Postest

\begin{tabular}{ccc}
\hline Kelompok Perlakuan & $\begin{array}{c}\text { Prosentase } \\
\text { Perubahan } \\
(\%)\end{array}$ & Keterangan \\
\hline Kontrol Positif (T1) & 4,3 & Menurun \\
Perlakuan 1 (T2) & 6,5 & Menurun \\
Perlakuan 2 (T3) & 8,5 & Menurun \\
Perlakuan 3 (T4) & 12,4 & Menurun \\
Perlakuan 4 (T5) & 13,7 & Menurun \\
\hline
\end{tabular}

jaringan dari Asetil Ko-A dan merupakan prekursor utama semua steroid lain dalam tubuh, jika jumlahnya berlebihan akan menyebabkan kolesterol dalam tubuh meningkat (Ramadhan, 2010).

Tabel 1 menunjukkan kadar kolesterol total (pre test) antar kelompok tidak ada perbedaan yang signifikan karena semua kelompok diberikan diet otak sapi dengan dosis yang sama yaitu 2 ml/tikus/hari. Hasil uji One Way Anova kadar kolesterol total setelah perlakuan (post test) diperoleh bahwa ada perbedaan kadar kolesterol total tikus yang signifikan antara kelima kelompok perlakuan sesudah intervensi pepino dan obat simvastatin. Perbedaan kadar kolesterol total post test dikarenakan pemberian buah pepino yang berbeda pada masing-masing perlakuan yaitu perlakuan pertama $9 \mathrm{gr} / 200 \mathrm{gr} \mathrm{BB} / \mathrm{hari}$, perlakuan kedua $10 \mathrm{gr} / 200 \mathrm{gr} \mathrm{BB} / \mathrm{hari}$ dan perlakuan ketiga $11 \mathrm{gr} / 200 \mathrm{gr} \mathrm{BB} / \mathrm{hari}$ dan perlakuan obat simvastatin $0,18 \mathrm{gr} / 200 \mathrm{gr}$ BB tikus.

Tabel 1 juga menunjukkan adanya perbedaan yang signifikan terhadap kadar kolesterol total pre dan post test yang ditandai dengan notasi $b$ pada kelompok perlakuan 1, perlakuan 2, perlakuan 3 dan perlakuan obat ( $\mathrm{p}<$ 0,05). Tabel 2 menunjukkan prosentase perubahan kadar kolesterol total antar kelompok. Diperoleh bahwa kelompok kontrol positif mengalami penurunan sebesar 4,3\%, dan semakin besar dosis buah pepino yang diberikan akan semakin besar pula prosentase penurunan kadar kolesterol totalnya.

Penurunan kadar kolesterol total secara signifikan pada tikus dengan pemberian buah pepino kemungkinan disebabkan oleh kandungan serat yang dapat menurunkan sintesis kolesterol. Lupton (2000) menyatakan serat akan mengikat kolesterol dan asam empedu yang membentuk misel di dalam usus halus, asam empedu dihasilkan oleh hati dikirim oleh hati ke usus halus kemudian mengikat kolesterol membentuk misel, serat yang membawa misel (asam empedu berikatan dengan kolesterol) akan di bawa ke usus besar (kolon) untuk di proses selanjutnya. Serat

akan difermentasi di kolon dan menghasilkan asam-asam lemak rantai pendek seperti asetat, propionate dan butirat. Propinat setelah masuk peredaran darah dan masuk ke hepar dapat menghambat kerja enzim HMG-KoA reduktase yang pada akhirnya sentesis kolesterol menjadi berkurang.

Selain serat vitamin $C$ juga bisa menurunkan kadar kolesterol. Penelitian yang dilakukan oleh Smith \& Alan (2006) menunjukkan bahwa defisiensi vitamin $\mathrm{C}$ menyebabkan penurunan produksi garam empedu dan peningkatan kadar kolesterol total. Pemberian vitamin C menyebabkan peningkatan pembentukan garam empedu yang akan memecah kolesterol dalam usus dan akan dibuang melalui feses. Penurunan kadar LDL dan HDL kolesterol setelah pemberian vitamin $\mathrm{C}$ disebabkan oleh peningkatan pembentukan garam empedu sehingga kolesterol yang merupakan bahan utama pembentukan garam ini banyak diambil dari dalam darah. Pemberian vitamin $\mathrm{C}$ dapat menekan produksi enzim HMGKoA reduktase sehingga kolesterol akan menurun.

Selisih kadar kolesterol total sebelum dan sesudah perlakuan diuji dengan menggunakan Mann-Whitney diperoleh bahwa tidak terdapat perbedaan yang signifikan pada kelompok perlakuan 3 dan obat, sehingga dapat dikatakan bahwa perlakuan 3 yaitu pemberian buah pepino dosis $11 \mathrm{gr} / 200$ gr BB tikus setara dengan kelompok yang diberi obat simvastatin $0,18 \mathrm{gr} / 200$ gr BB tikus.

Pemberian buah pepino dapat menurunkan kadar kolesterol total, namun penurunannya sesuai dengan dosis yang diberikan pada tikus. Dosis I menurunkan kadar kolesterol total 6,5\%, dosis II menurunkan $8,5 \%$, dan penurunan lebih banyak pada dosis III yaitu penurunan sebesar $12,4 \%$. Dosis III sebagai dosis terbesar yaitu $11 \mathrm{gr} / 200 \mathrm{gr}$ BB/hari menurunkan kadar kolesterol lebih banyak daripada dosis I dan II. PERKI (2001) menyatakan bahwa 25-30 gram serat per hari merupakan bagian dari diet rendah lemak sehingga dapat mengurangi risiko penyakit jantung dan aterosklerosis. 
Tabel 3 Hasil Uji Mann-Whitney Selisih Kadar Kolesterol Total

\begin{tabular}{llllll}
\hline Perlakuan & $\mathrm{K}+$ & P1 & P2 & P3 & Obat \\
K + & & NS & $(*)$ & $(*)$ & $(*)$ \\
P1 & - & & NS & $(*)$ & $(*)$ \\
P2 & - & - & & $(*)$ & $(*)$ \\
P3 & - & - & - & & NS \\
Obat & - & - & - & - & \\
\hline (*) : berbeda signifikan & & \\
NS & : tidak berbeda signifikan
\end{tabular}

\section{KESIMPULAN DAN SARAN \\ Kesimpulan}

Berdasarkan hasil penelitian yang telah dilakukan dapat disimpulkan sebagai berikut:

1. Ada efek pemberian buah pepino terhadap perubahan kadar kolesterol total pada tikus hiperkolesterolemia.

2. Ada perubahan kadar kolesterol total tikus sebelum dan sesudah perlakuan, yaitu perlakuan pertama $67 \mathrm{mg} / \mathrm{dl}$ menjadi $62,6 \mathrm{mg} / \mathrm{dl}$, perlakuan kedua 70,4 mg/dl menjadi $64,4 \mathrm{mg} / \mathrm{dl}$ dan perlakuan ketiga $69,4 \mathrm{mg} / \mathrm{dl}$ menjadi $60,8 \mathrm{mg} / \mathrm{dl}$.

3. Ada perbedaan prosentase perubahan kadar kolesterol total pada dosis I, II, III pemberian buah pepino yaitu sebesar $6,5 \%, 8,5 \%$ dan $12,4 \%$, dimana pemberian simvastatin menurunkan $13,7 \%$.

4. Tidak terdapat perbedaan pemberian kadar kolesterol total antara pemberian buah pepino dosis III dengan simvastatin.

\section{Saran}

1. Perlu pengkajian lebih lanjut terkait lama waktu dan dosis pemberian buah pepino terhadap kadar kolesterol total.

2. Perlu pengkajian lebih lanjut terkait dengan kandungan serat dan antioksidan pada diet standar atau pakan tikus, untuk mengetahui pengaruh terhadap kadar kolesterol total.

\section{DAFTAR PUSTAKA}

Guyton, A.C. \& Hall, J.E. 2006. Text Book of Medical Physiology, 11 Editions

Husnah, M., 2009. Identifikasi Dan Uji Aktivitas Golongan Senyawa Antioksidan Ekstrak Kasar Buah Pepino ( Solanum Muricatum Aiton) Berdasarkan Variasi Pelarut. Skripsi. Malang: UIN
IPGRI. 2004. Descriptors of Pepino, Solanum Muricatum, International Plan Genetic Resources Institude. ISBN 92-9034-616-6, http//www.ipgri.cgiar.org. diakses 19 Januari 2013

Khayrani, A. Cahya. 2008. Jurnal : Pengaruh Konsentrat Protein Kacang Komak (Lablab purpureus (L) Sweet) Terhadap Kadar Glukosa Darah, Profil Lipid, Dan Peroksidasi Lipid Tikus Diabetes. Bogor: Institut Pertanian Bogor.

Lupton, JR., Turner, D., 2000. Dietary Fiber. In : Biochemical and Physiological Aspect of Human Nutrition. London: WB Saunders Company.

Nainggolan, O dan C. Adimunca, 2005. Diet Sehat Dengan Serat. Cermin Dunia Kedokteran No. 147, Departemen Kesehatan RI, Jakarta.

Notoatmodjo, Soekidjo. 2010. Metodologi Penelitian Kesehatan. Jakarta : Rineka Cipta.

Ramadhan, F.F. 2011. Pengaruh Pemberian Nata de Coco terhadap Kadar Kolesterol Total dan Trigliserida pada Tikus Hiperkolesterolemia. Skripsi. Program Studi Ilmu Gizi Fakultas Kedokteran Universitas Diponegoro Semarang.

Rohmawati, Erma. 2008. Pengaruh Fraksi Nonprotein Kacang Komak (Lablab Purpureus (L.) Sweet) Terhadap Kadar Glukosa Darah, Profil Lipid, dan Peroksidasi Lipid Tikus Diabetes. Skripsi. Bogor. IPB. 
Puguh,Rindiani, dan Dahlia Indah A, Efek Pemberian Buah Pepino (Solanum maricatum) Terhadap Perubahan Kadar Kolesterol Total Pada Tikus Hiperkolesterolemia 